Johnstone, D. B. \& Fishbein, J. R. (1956). J. gen. Microbiol, 14, 330-335

\title{
Identification of Azotobacter Species by Fluorescence and Cell Analysis
}

\author{
By D. B. JOHNSTONE AND J. R. FISHBEIN \\ Department of Agricultural Biochemistry, University of Vermont, Burlington, \\ Vermont, U.S.A.
}

SUMMARY : Eight strains of Azotobacter agile and $A$. vinelandii were studied for their ability to elaborate water soluble compounds with a fluorescence that would characterize each when observed under ultraviolet light of $3600 \mathrm{~A}$. It was found that the material produced by $A$. agile fluoresced white, whereas that produced by $A$. vinelandii fluoresced green. Additional studies with iron and molybdenum showed that molybdenum enhanced synthesis of fluorescent material in both species and iron appeared to quench the fluorescence. A pH/fluorescence curve for the fluorescent material of each species showed that, although similarities were evident, sufficient difference existed to permit recognition of each. Analyses of dried cell material revealed a much higher protein content in $A$. agile than in $A$. vinelandii, but the amount of one of their amino acids, lysine, was essentially the same, on the basis of protein, for each species.

Production of fluorescent pigments by the azotobacters has long been known. Even Beijerinck's (1901) first description of Azotobacter agile mentioned the existence of a greenish yellow pigment resembling that in fluorescent bacteria. Since that time, references to pigments of this nature have been repeatedly mentioned in connexion with azotobacter, and occasionally they have been of taxonomic significance. In none of these reports was there ever mentioned the use of ultraviolet light to observe the characteristic fluorescence. It is assumed, therefore, that in most, if not all, instances the observations for fluorescent pigments were made in normal daylight. Johnstone (1955) reported that the use of ultraviolet light of $3600 \mathrm{~A}$ was useful in observing the production of fluorescent substances produced by $\boldsymbol{A}$. agile Beijerinck and $\boldsymbol{A}$. vinelandii Lipman, and this prompted us to investigate other strains of each species to see if they too would emit fluorescent light with a characteristic colour when excited by ultraviolet light. The present paper deals with this investigation, and also presents an analysis of cell material, contributing further information which we hope will be useful in separating $A$. agile from $A$. vinelandii. A recent paper (Schutter \& Wilson, 1955) also pointed out some new biochemical approaches toward taxonomic identification of these two species.

\section{METHODS}

Ultraviolet light observation. Sixteen strains obtained from various laboratories, and including our own isolates, are listed in Table 1. Burk's nitrogenfree agar (Wilson \& Knight, 1952) with $2 \%$ (w/v) glucose was used for growth, and after 4 days of incubation at $30^{\circ}$ the cultures were observed in the dark under ultraviolet light of $3600 \mathrm{~A}$ for colour differences in fluorescence. 
Influence of iron and molybdenum. An experiment designed to show the effect of iron and molybdenum on the production of the characteristic yellowish green pigment by Azotobacter vinelandii (Wilson \& Knight, 1952) involved liquid cultures with increasing amounts of iron in the form of $\mathrm{FeSO}_{4} \cdot 7 \mathrm{H}_{2} \mathrm{O}$ or molybdenum in the form of $\mathrm{MoO}_{3}$, or both. The iron was incorporated in Burk's nitrogen-free medium in $0,0 \cdot 01,0 \cdot 1,1 \cdot 0$ and 10 p.p.m. The molybdenum was

Table 1. Source of strains of azotobacter

\begin{tabular}{|c|c|c|c|c|c|c|c|}
\hline \multicolumn{4}{|c|}{ Azotobacter agile } & \multicolumn{4}{|c|}{ Azotobacter vinelandii } \\
\hline Strain & Laboratory & Location & No.* & Strain & Laboratory & Location & No. \\
\hline 103 & J. Smit & Holland & $\dagger$ & 102 & ATTC & Washington & 9046 \\
\hline 127 & J. Smit & Holland & S1 & 107 & H. L. Jensen & Denmark & M 2 \\
\hline 106 & H. L. Jensen & Denmark & $\mathbf{S}$ & 120 & P. W. Wilson & Wisconsin & $\mathbf{0}$ \\
\hline 122 & P. W. Wilson & Wisconsin & $4 \cdot 4$ & 121 & P. W. Wilson & Wisconsin & 3 \\
\hline 123 & P. W. Wilson & Wisconsin & $\mathbf{S}-2$ & 129 & C. B. van Niel & California & MB $3 \cdot 1$ \\
\hline 124 & P. W. Wilson & Wisconsin & S-4 & 1 & D. Johnstone & Vermont & - \\
\hline 130 & C. B. van Niel & California & MB $4 \cdot 4$ & $3 \mathbf{a}$ & D. Johnstone & Vermont & - \\
\hline 131 & C. B. van Niel & California & MB $4 \cdot 5$ & $3 \mathrm{~b}$ & D. Johnstone & Vermont & - \\
\hline
\end{tabular}

present in $0,0 \cdot 001,0 \cdot 01,0 \cdot 1$ and $1 \cdot 0$ p.p.m. Duplicate series of these media were prepared. One series was inoculated with a strain of $A$. agile, the other series with a strain of $A$. vinelandii which were incubated at $30^{\circ}$ on a rotary shaking machine for a period of 5 days. It was reasoned that if iron and molybdenum influenced the production by $A$. vinelandii of pigment visible in daylight, it might well influence the fluorescent material.

Influence of $\mathrm{pH}$ value on fluorescent pigments. It has been shown to be of interest to obtain a $\mathrm{pH} /$ fluorescence curve or the amount, expressed in per cent, of fluorescent light emitted at different $\mathrm{pH}$ values, to characterize partially a fluorescent compound (Goodwin, 1953). The organisms were removed from a culture by centrifugation, the supernatant fluid placed in buffer at different $\mathrm{pH}$ values, and the relative fluorescence was read on a Klett fluorimeter. The procedure followed was essentially the same as employed by Kavanagh \& Goodwin (1948), but with buffer solutions made from Coleman buffer tablets. The instrument was adjusted to read 100 on a linear scale with a quinine standard ( $1 \mathrm{mg}$. quinine sulphate/l. of $0 \cdot 1 \mathrm{~N}-\mathrm{H}_{2} \mathrm{SO}_{4}$ ). With the sample showing maximum fluorescence adjusted to $100 \%$, the other values were read relative to it in per cent.

Analysis of dried cell material. In an effort to characterize further the two species, Azotobacter agile and $A$. vinelandii, it was thought desirable to see whether or not there were any differences in protein content. A series of analyses was obtained on dry cell material. Two different strains of each species were grown, in duplicate lots, in $6 \mathrm{l}$. fermentors. Burk's nitrogen-free medium was employed, and the cultures aerated at approximately $6 \mathrm{l} . / \mathrm{min}$. After 6 days of incubation at $30^{\circ}$ the cell material was harvested by a Sharples centrifuge and air-dried at $70^{\circ}$. The cell material was analysed in duplicate, thus 
making a total of sixteen samples for analysis. Total nitrogen was determined by a micro-Kjeldahl procedure and the total protein was computed from this. The ash content was desired to show that organism weight was not greatly affected by salts, and was obtained by ignition at $600^{\circ}$ for $4 \mathrm{hr}$. The amount of lysine was desired to know whether or not the protein of related species is similar. Lysine was selected arbitrarily because it is known to be synthesized in appreciable quantities by organisms of this genus, and because reliable microbiological procedures for its assay are available. The lysine determinations were made microbiologically by assaying hydrolysed cell protein with Leuconostoc mesenteroides and measuring the response turbidimetrically with a Coleman Universal colorimeter.

\section{RESULTS}

Observations in ultraviolet light

The observation of the cultures in Table 1 under ultraviolet light revealed a striking difference between the two species. The strains of Azotobacter agile showed soluble material which fluoresced a brilliant white, whereas the strains of $A$. vinelandii showed soluble material which fluoresced green. Most strains of both species developed a yellowish green pigment which was visible in normal daylight; this was more pronounced with $A$. vinelandii. Further studies with liquid cultures paralleled the observations with those grown on an agar medium. However, the development of a yellowish green pigment in $A$. agile did not alter the colour of brilliant white fluorescence observed under ultraviolet light. In fact, one strain produced a water-soluble dark brown pigment, but the culture still fluoresced like the other strains of $A$. agile. All thesestrains of $A$. agile failed to grow on mannitol as the sole source of carbon, thus confirming the observation of Kluyver \& van den Bout (1936). On the other hand, all strains of $A$. vinelandii grew luxuriantly on this substrate, confirming the report of Schutter \& Wilson (1955).

\section{Influence of iron and molybdenum}

The effects of adding iron or molybdenum were twofold. In Azotobacter vinelandii, iron appeared to stimulate cell synthesis to a marked degree, but quenched the production of the yellowish green pigment. In the higher concentrations of iron a brownish pigment developed. Molybdenum, on the other hand, appeared to favour the synthesis of the yellowish green pigment but was not particularly stimulatory to cell synthesis. Obviously, it is unlikely that the media without added iron or molybdenum were entirely free of either substance. When this series of flask cultures was viewed under ultraviolet light, the brilliant green fluorescence was most intense in those flasks containing added molybdenum but not iron. It was still observable in molybdenumcontaining cultures which also contained 0.1 p.p.m. iron, but was completely quenched by 1.0 p.p.m. iron at all concentrations of molybdenum. A moderate amount of growth and fluorescent material was formed in the absence of added iron and molybdenum. 
Identical results were obtained with Azotobacter agile except that little or no pigment was observed in daylight. Under ultraviolet light the brilliant white fluorescence showed the same pattern of response to iron and molybdenum as was found for A. vinelandii. Schutter \& Wilson (1955), reporting on the cultivation of each species in the absence of added iron or molybdenum, stated that A. vinelandii strains turned the medium a light green, whereas the colour formed by $A$. agile was less intense. Had they observed these under ultraviolet light they probably would have seen considerable fluorescence in both species.

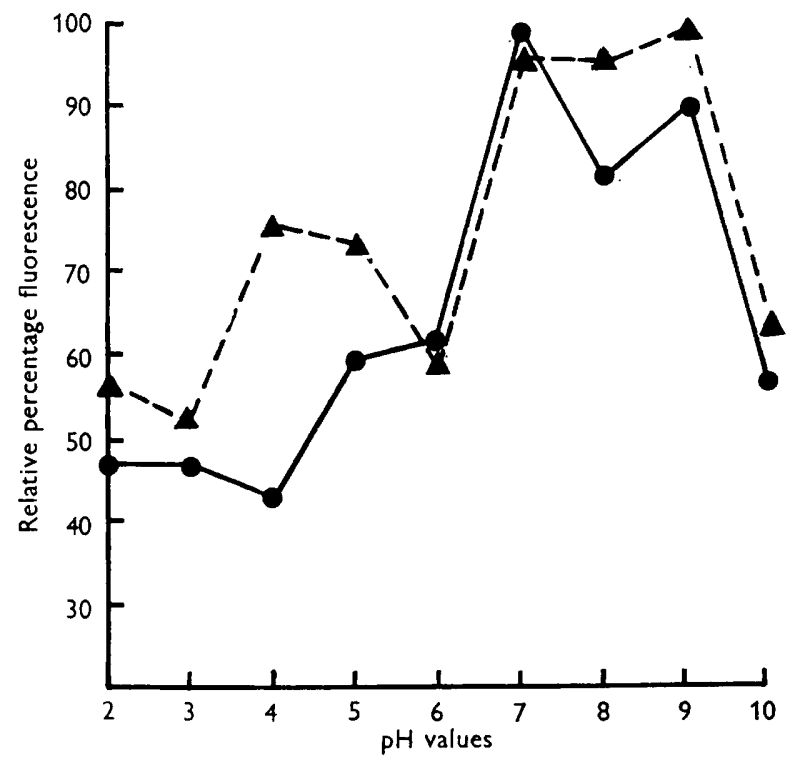

Fig. 1. The $\mathrm{pH} /$ fluorescence curves for the culture fluids of cultures of Azotobacter vinelandii $3 \mathrm{a}$ and 1 , agile 106.

$3 \mathbf{a} ; \boldsymbol{\Delta}---\boldsymbol{\Delta}, 106$.

\section{Influence of $\mathrm{pH}$ value on fluorescent pigments}

Fig. 1 shows the percentage of light emitted by the culture filtrate of Azotobacter vinelandii 3 a when adjusted to different $\mathrm{pH}$ values and read on a Klett fluorimeter. The peak of light emission appeared at $\mathrm{pH} 7$ and decreased above and below this $\mathrm{pH}$ value. However, there was still considerable fluorescence observable by the naked eye when viewed under ultraviolet light at $\mathrm{pH}$ values as low as 5 and as high as 10 . Though the fluorimeter did not distinguish between the two colours emitted by the two species, it did yield a $\mathrm{pH} /$ fluorescence curve for the culture filtrate of $A$. agile (Fig. 1), which showed a remarkable similarity to that of $A$. vinelandii, but sufficiently different to permit a distinction to be made between the two micro-organisms. The culture filtrate of $A$. agile showed a secondary peak of fluorescence at $\mathrm{pH} 4$ not found in the material elaborated by $A$. vinelandii. 


\section{Analysis of cell material}

Table 2 shows the average results of analyses for protein (based upon microKjeldahl total nitrogen), ash and lysine. The amount of cell protein based upon cell weight was markedly different for the two species, Azotobacter agile containing almost twice the amount found in $A$. vinelandii. Since the percentage

Table 2. Average analyses of dried cell material

\begin{tabular}{|c|c|c|c|c|c|}
\hline \multirow[b]{2}{*}{ Organism } & \multirow[b]{2}{*}{$\begin{array}{c}\text { Protein } \\
(\%)\end{array}$} & \multirow[b]{2}{*}{$\begin{array}{l}\text { Ash } \\
(\%)\end{array}$} & \multicolumn{3}{|c|}{ Lysine* } \\
\hline & & & $(\mu \mathrm{g} . / \mathrm{mg} \cdot \mathrm{CM})$ & $(\mu \mathrm{g} \cdot / \mathrm{mg} \cdot \mathbf{P})$ & $(\%)$ \\
\hline A. agile 103 & $31 \cdot 1$ & $7 \cdot 3$ & 16 & 51 & $5 \cdot 1$ \\
\hline A. agile 106 & $29 \cdot 4$ & $6 \cdot 2$ & $13 \cdot 6$ & 46 & $4 \cdot 6$ \\
\hline A. vinelandii 102 & $16 \cdot 7$ & $7 \cdot 0$ & $8 \cdot 3$ & 49 & $4 \cdot 9$ \\
\hline A. vinelandii $\mathbf{3 a}$ & $13 \cdot 8$ & $4 \cdot 0$ & $7 \cdot 2$ & 51 & $5 \cdot 1$ \\
\hline
\end{tabular}

of ash was not great and the amounts were similar, salts can be ruled out as accounting for a variation in cell weight. The protein is based upon total nitrogen, and as a fixed form of nitrogen was not added to the medium, and as the cell slime does not contain nitrogen, it can be assumed that figures for protein/unit weight of cell material represent the protein of the organisms. The apparent differences in amount for the two species may be due to a difference in the amount of polysaccharide slime in the dried cell material, and hence may represent a difference in slime synthesis. Whatever the reason, the difference is sufficiently pronounced to offer an additional character for taxonomic separation of the two species. Though the amount of lysine/unit weight of cell material differed with each species, as might be expected from the protein determinations when expressed per unit weight of protein, the values are remarkably similar and show that, though protein may be of different quantity per unit weight of cells, at least one of the individual amino acids occurred in the same proportion in both species.

\section{DISCUSSION}

The suggestion was made (Johnstone, 1955) that the production of fluorescent substances by micro-organisms might be of considerable taxonomic significance if observations be made with a suitable source of ultraviolet light. This is now amplified by these investigations, which have shown that all $A$ zotobactervinelandii strains so far tested, when grown in a medium low in iron, produce material which fluoresces green under ultraviolet light, while under the same conditions A. agile strains fluoresce white. It is of additional importance that none of the 16 strains in Table 1 have lost this ability nor have any other strains of this genus been shown to acquire it during an observation period of one year. The quantity of fluorescent material elaborated by each species varied from strain to strain. These materials produced by each species are not a temporary phenomenon during the growth of the cultures, but once formed are permanent and 
stable to heat. They withstand autoclaving without apparent alteration. It might be pointed out that we have received two additional strains labelled $A$. agile, neither of which produces any fluorescent material. Both these strains appear to have all the characteristics of $A$. agile, including an inability to grow on mannitol as the sole source of carbon. It is not surprising to find strains of any group of micro-organisms which differ from the normal pattern by not forming some metabolic product. If they had produced the fluorescent substance characteristic of the other species, $A$. vinelandii, while retaining other characteristics of $A$. agile, there would be some concern. Therefore, it is felt that the use of ultraviolet light, while not always sufficient in itself, is of additional help in separating these two species.

It is not conclusive on the basis of four strains, but perhaps indicative, that Azotobacter agile produces considerably more protein on the basis of cell weight than the amount synthesized by $A$. vinelandii under the experimental conditions used. This means that micro-Kjeldahl analysis for total nitrogen of each species will reveal a difference which again may be helpful in separating the two species.

We are indebted to R. H. Goodwin, Connecticut College, New London, Connecticut, for his kindly advice and for permitting us the use of his fluorimeter for the $\mathrm{pH} /$ fluorescence curves. We are also indebted to J. Smit of Wageningen, Holland; H. L. Jensen of Lyngby, Denmark; M. Alexander of University of Wisconsin; and C. B. van Niel of Pacific Grove, California, for kindly supplying certain cultures during the course of this work. The study was supported by the State of Vermont; this is a contribution from the Vermont Agricultural Experiment Station, Journal Series Paper no. 56.

\section{REFERENCES}

BeiJerinck, M. W. (1901). Über oligonitrophile Mikroben. Zbl. Bakt. (2. Abt.), 7, 561.

Goodwin, R. H. (1953). Fluorescent substances in plants. Annu. Rev. Pl. Physiol.4, 283.

Johnstone, D. B. (1955). Azotobacter fluorescence. J. Bact. 69, 481.

Kavanagh, F. \& Goodwin, R. H. (1948). The relationship between $\mathrm{pH}$ and fluorescence of several organic compounds. Arch. Biochem. 20, 315.

Kluyver, A. J. \& van Den Bout, M. T. (1936). Notiz über Azotobacter agilis Beijerinck. Arch. Mikrobiol. 7, 261.

Schutter, J. \& Wilson, P. W. (1955). Patterns of enzymic adaptation in species of the genus Azotobacter. J. gen. Microbiol. 12, 446.

Wilson, P. W. \& Knight, S. G. (1952). Experiments in Bacterial Physiology. Minneapolis, Minn.: Burgess Publishing Co.

(Received 16 September 1955) 